\title{
Lumen
}

Selected Proceedings from the Canadian Society for Eighteenth-Century Studies

\section{'Dire Compotation': Eighteenth-Century English Georgics and the (Mis)Uses of Alcohol}

\section{Kelly Ann Mcguire}

Volume 23, 2004

URI : https://id.erudit.org/iderudit/1012198ar

DOI : https://doi.org/10.7202/1012198ar

Aller au sommaire du numéro

Éditeur(s)

Canadian Society for Eighteenth-Century Studies / Société canadienne d'étude du dix-huitième siècle

ISSN

1209-3696 (imprimé)

1927-8284 (numérique)

Découvrir la revue

Citer cet article

Mcguire, K. A. (2004). 'Dire Compotation': Eighteenth-Century English Georgics and the (Mis)Uses of Alcohol. Lumen, 23, 255-273.

https://doi.org/10.7202/1012198ar

Copyright (C Canadian Society for Eighteenth-Century Studies / Sociéte canadienne d'étude du dix-huitième siècle, 2004
Ce document est protégé par la loi sur le droit d'auteur. L'utilisation des services d'Érudit (y compris la reproduction) est assujettie à sa politique d'utilisation que vous pouvez consulter en ligne.

https://apropos.erudit.org/fr/usagers/politique-dutilisation/ 


\section{4. 'Dire Compotation': Eighteenth-Century English Georgics and the (Mis)Uses of Alcohol}

Amidst the substantial arsenal of literary terms invoked by critics in attempts to define the georgic, by far the most popular is the adjective 'protean. ${ }^{1}$ This epithet might be suitably applied not only to the mutable, unstable nature of the form, but also to the Odyssean effort entailed in approaching it as a subject of study, since the georgic regularly defies the limits of genre and resists the categories by which critical discourse attempts to define it. This recalcitrance has distinguished the form since its inception, ${ }^{2}$ and its successors inevitably inherit the 'radical indeterminacy' that besets the classical Virgilian model. No actual consensus exists concerning how the georgic precisely ought to be defined, with numerous critics even taking issue with approaches that address the literature in exclusively generic terms. Finding in the georgic 'an informing spirit... an attitude toward life...' (p. 7), Anthony Low designates it as a mode rather than a genre, while Kurt Heinzelman hails it as a 'genre that is not one... [neither] confined to poetry nor even enclosed by the sign of the "literary". ${ }^{3}$ More recently, Frans De Bruyn has attributed this

1 Kurt Heinzelman refers to the georgic as a 'protean discursive form' ('Roman Georgic in the Georgian Age: A Theory of Romantic Genre,' Texas Studies in Language and Literature 33 (1991): p. 190), while in his recent article 'the Georgic at Mid-Eighteenth Century and the Case of Dodsley's "Agriculture,"' Juan Christian Pellicer describes the georgic as a 'notoriously protean genre' (Review of English Studies 54, no. 213 (2003): p. 67).

2 Among the various classicists who have most recently directed their critical attention to book-length studies of Virgil's Georgica, Stephanie Nelson locates 'unresolved tensions' in the Georgics, while Monica Gale more recently acknowledges that the work 'leaves us with no clear answers, though it raises many questions' (God and the Land: the Metaphysics of Farming in Hesiod and Vergil (New York: Oxford University Press, 1998) p. 5).

3 Anthony Low, The Georgic Revolution (Princeton: Princeton University Press, 1985), p. 197. 
typological quandary to mistakenly imposed distinctions between factual and imaginative literature upon 'an abashedly factual, didactic mode of writing' practically incomprehensible to the modern sensibility. ${ }^{4}$ Moreover, the georgic's firmly entrenched socio-cultural and ideological facets have dominated discussion since Raymond Williams' seminal study in The Country and the City, while critics such as Karen $\mathrm{O}^{\prime}$ Brien and Rachel Crawford have of late uncovered the 'aristocratic biases' and 'imperial ethos' so intrinsic to the form. ${ }^{5}$

The pervasive mood of the georgic has, however, proved easier to isolate. Perhaps undeservedly, the Virgilian georgic has incurred censure as 'a profoundly gloomy work, ${ }^{\prime 6}$ and numerous critics identify as its distinguishing feature a sobriety of both tone and thematic substance. Yet, despite, or perhaps owing to, its earnest engagement with the mundane, the genre attracts considerable parodic attention in the eighteenth century and spawns a host of mock-georgics, including John Philips' ‘Cerealia' (1707), John Gay's 'Wine' (1708), and Thomas Parnell's 'Bacchus; or, a Drunken Metamorphosis' (1734). Simultaneously, the Virgilian original affords a blueprint for a nationalistic literature ${ }^{7}$ and supplies the model for formal English georgics such as Philips' Cyder (1708), Christopher Smart's The Hop-Garden (1752), and James Grainger's

4 Frans De Bruyn, 'From Virgilian Georgic to Agricultural Science: An Instance in the Transvaluation of Literature in Eighteenth-Century Britain,' Augustan Subjects: Essays in Honor of Martin C. Battestin (London: University of Delaware Press, 1997), p. 49.

5 In her recent book-length study, Rachel Crawford ascribes the 'imaginative appeal' of the georgic to its 'aristocratic bias' (Poetry, Enclosure, and the Vernacular Landscape, 1700-1830 (Cambridge: Cambridge University Press, 2002), p. 97), and while it might be oversimplifying the matter to argue for such a simple class-division at work within the form that achieved full popularity at a time when English society was moving away from a clear-cut, binary model, such a reading seems to take into full account the full scope of the socio-cultural agenda embedded in the genre.

6 Monica R Gale, Virgil on the Nature of Things. The Georgics, Lucretius and the Didactic Tradition (Cambridge: Cambridge University Press, 2000), p. ix.

7 Many of these poems are drawn from different periods of eighteenth-century history, representing the reigns of several monarchs and reflective of the most significant historical developments of their day. Yet, apart from their form, they all share as a common concern a strong nationalist, reactionary bias as symbolized by the national product that is extolled in each. The land in each is described in terms of its crop and takes its nominal identify from the eulogized product itself. The project in these poems is to elevate the crop to the status of a national treasure or resource and to distinguish it from its foreign equivalent. Whereas Virgil's project is to direct but also to extol the industry of the 'husbandman,' the concern of his English successors is to exalt the fruit of his labour as a national and imperial symbol. 
Sugar-Cane (1764). The mock and serious georgics of the period share as a common feature a concern with alcohol, a peculiarity that merits some scrutiny given the genre's 'sober' disposition and its preoccupation with imposing order upon nature. Although many georgics of the period focus upon an assortment of crops, several of the century's major experiments in the form immerse themselves specifically in viticulture, adopting thereby one aspect of husbandry for their subject matter and departing significantly from Virgil, whose concern encompasses the wide sweep of agriculture. But, the texts' interest in alcohol ventures beyond the minutiae of the cultivation and processing of the product in its various forms as they explore the genre's imperial, national and social possibilities. Alcohol saturates these georgics, representing both a product of labour and an item of consumption. Its presence in these texts collapses the boundary between labour and leisure, introducing difficulties on a generic level given the tendency to align the georgic with production and to reserve consumption as the province of the pastoral. Although the affinity of the georgic for straying into the pastoral realm is a well-documented phenomenon, ${ }^{8}$ the significant role enacted by consumption in this context has been generally ignored. Paradoxically, even while alcohol consumption enables georgic poets to dissolve genre divisions, it also serves to reinforce the class boundaries that were in the process of becoming much more fluid in this period. In its attempt to account for the suffusion of spirits in a host of eighteenth-century georgics, my discussion must both consider these works alongside contemporaneous experiments in the form and distinguish them from topoi of the Virgilian model. While this treatment of the historical and political permutations of eighteenth-century English georgics must inevitably

8 In her discussion of 'Imperial Georgic', Karen O'Brien alludes to the creation of a 'residually pastoral idiom for imperial georgic' ('Imperial georgic, 1660-1789,' The Country and the City Revisited: England and the Politics of Culture, 1550-1850, Gerald MacLean ed., (Cambridge: Cambridge University Press, 1999), p. 168) to support a nationalistic message. The distinction between the genres, however, is often ignored as the georgic is so often subsumed into the category of the pastoral. The chronic conflation of pastoral and georgic modes takes place within Virgil's work itself, in which, according to Raymond Williams, 'a transmutation occurs' as in some parts the 'landscape becomes more distant, becomes in fact Arcadia, and the Golden Age is seen as present' (The Country and the City (New York: Oxford University Press, 1973), p. 68). Although the vast majority of contemporary critics express a concern to differentiate decisively between the pastoral and the georgic on the basis of the time-honoured opposition of otium and negotium, an extraordinary degree of slippage is discernible between the two modes. 
contour itself around questions of genre, it is the 'socio-symbolic' dimension of genre that I primarily wish to highlight. ${ }^{9}$ The flexible, heterogeneous makeup of the georgic allows it to incorporate the labouring poor into a vision of a harmonious community, even while it reduces them to the status of a commodity.

In identifying the 'emphasis upon agricultural and manufacturing labor and production, rather than consumption' as a 'notable feature of eighteenth-century georgic poems' (p. 166), Karen O'Brien subscribes to the assumptions that generally inform contemporary criticism of these works. The inculcation of the Protestant work ethic is generally deemed one of the central preoccupations of the English georgics, which in turn draw upon Virgil's own tendency to reject luxury in favour of labour, even when he qualifies it with such adjectives as durus or magnus. ${ }^{10}$ Indeed, John Dyer's eulogy to labor in The Fleece that culminates in his recommendation that 'Houses of labor, seats of kind constraint' be raised 'through ev'ry province' (3.62-63), ${ }^{11}$ reinforces precisely the imperative to produce so integral to the georgic. As Rachel Crawford observes, the idealizing tone of the passage masks the grim project of 'policing the poor into industry as a solution to inadequate supplies of bread..$^{12}$

This zealous promotion of rigorous toil resounds throughout the georgics, a scarcely surprising theme in a form that 'takes the economic value of labour as its subject. ${ }^{13}$ James Thomson's emphatic recommendation of 'unambitious toil'14 in The Seasons finds an echo throughout a cluster of georgics, which seek to preclude the prospect of upward mobility through their consistent equation of labour with virtue.

Given the undeniably close affiliations between the georgic and modes of production, it seems reasonable to assume that any factor

9 The georgic appears to function in a manner suggestive of the Jamesonian notion of genre as 'essentially a socio-symbolic message... imminently and intrinsically an ideology in its own right' (Fredric Jameson, The Political Unconscious: Narrative as a Socially Symbolic Act (Ithaca: Cornell University Press), 1981, p. 141).

10 Gale, Virgil on the Nature of Things, p. 144.

11 John Dyer, The Fleece, in Minor Poets of the Eighteenth Century: Parnell, Green Dyer $\mathcal{E}$ Anne, Countess of Winchilsea, ed. Hugh I'Anson Fausset (London: J.M. Dent, 1930). All subsequent references of the poems are to book and line.

12 Crawford, Poetry, p. 101.

13 Williams, p. 43.

14 James Thomson, 'Autumn,' The Seasons and the Castle of Indolence, ed. J. Logie Robertson (Oxford: Clarendon press, 1891), p. 276. 
perceived as inhibiting the labor of the working classes would be severely discouraged. Indeed, the potential that the product may diminish the productivity of the producer leads to the inclusion of certain safeguards to discourage over-consumption and preserve the body of the georgic labourer. To this end, John Armstrong's The Art of Preserving Health ${ }^{15}$ dwells at length upon the deleterious effects of 'drinking deep.' In this georgic, Armstrong recommends the salubrious effects afforded by the 'more voluptuous ... more sprightly draught' (2.434) of beer and wine, over those arising from 'wine unmix'd' (2.435). Although Armstrong takes the human body as his subject and in effect conceives of it as a field to be tilled, the theme of labour eventually overrides this concern, as he devotes by far the longest book in the georgic to recommending to the gentry the pleasures of exercise by idealizing 'the labourer of the glebe, who toils / In dust, in rain, in cold and sultry skies...' (3.19-20). At the outset of his discourse on exercise, Armstrong declares 'To you, ye delicate, I write' (3.8), explicitly acknowledging as his audience 'the polite English readership' that typically presides over reader reception of the georgics. In his preface to Dryden's translation of Virgil's Georgica, Joseph Addison emphatically insists that 'the precepts of Husbandry are not to be delivered with the simplicity of a plow-man, but with the address of a poet' (p. 212). The georgics suppress the voice of the labourer as they address themselves to the aristocratic landowners endowed with the leisure and the education to appreciate the precepts they expound. Given their audience, the preoccupation with monitoring production and vigilantly circumscribing habits and practices not conducive to this end inevitably asserts itself as a dominant theme in these works.

Moreover, the demand issued in a 1743 issue of the Gentleman's Magazine that 'all practices should be suppressed by which the lower Orders of the People are enfeebled and enervated' (p. 566) suggests the social awareness of the obstacles to productivity posed by alcoholic indulgence. Since, as Sarah Jordan observes, 'one of the most often-discussed attributes and signs of the grotesque, idle laboring class was drunkenness', ${ }^{16}$ eighteenth-century poets were inevitably sensitive to and appreciative of the need to address this problem in their georgic compositions. Even as early as Smart's time, the image of 'Merry Eng-

15 John Armstrong, The Art of Preserving Health (New York: Arno Press, 1979).

16 Sarah Jordan, 'From Grotesque Bodies to Useful Hands: Idleness, Industry, and the Laboring Class,' Eighteenth-Century Life 25, no. 3 (2001): p. 63. 
land' bidding its countrymen to drink deep was increasingly tarnished by the growing consumption of gin, ${ }^{17}$ since great numbers of 'his Majesty's subjects ... were by its use rendered unfit for useful labour, debauched in morals, and drawn into all manner of vice and wickedness' ${ }^{\prime 1}{ }^{18}$ In light of this trend, early georgics acknowledge the perils arising from the very products whose cultivation they promote. In a moment of stark realism, Philips dilates upon the evils attending the prolongation of 'dire compotation' that results in 'horrid frays' when '... brimming glasses are hurled / With dire intent; bottles with bottles clash / In rude encounter, round their temples fly / The sharp edg'd fragments, down their batter'd cheeks / Mix'd gore and cider flow' (2.45961). The final, appalling image of this tableau introduces a moralizing strain hitherto fairly understated in the poem; however, the digression on the perils of civil war that ensues effectively undermines the severity of this warning by raising an even more alarming concern. Philips retreats from the spectacle of over-indulgence at his earliest convenience. Dyer's mid-century georgic, The Fleece, deliberately excises drink from its 'board of smiling plenty's stores' (2.547), which marks the 'yearly festals' (2.540), during which the swains remain virtuously sober. But it is worth noting that alcohol insidiously creeps into this text by means of metaphors relating to trade. Dyer characterizes French 'industry,' accordingly, as an 'impious poison' (4.93) with the power to 'vitiate and emasculate the mind' (4.95), and bids the Europeans 'Blush ... whom the circling cup / Of luxury intoxicates' (4.542-43). Conversely, he admon-

17 As Rudi Matthee writes, 'In England ... gin began to rank with beer and ale as the favourite drink of the labouring classes in part as a result of a government promotion of indigenous spirits ... So popular did gin become among the masses that anxiety about the state of productivity and public morality led to a reversal in state policy in the form of the prohibitionist Gin Act (1736)' ('Exotic Substances: The Introduction and Global Spread of Tobacco, Coffee, Cocoa, Tea, and Distilled Liquor, Sixteenth to Eighteenth Centuries' in Drugs and Narcotics in History, ed. Roy Porter, (Cambridge: Cambridge University Press, 1995), p. 45). William Hogarth vividly evokes the evils of over-indulgence in his 1750 nightmare vision of 'Gin Lane.' Yet, as critics have noted, in Hogarth's 'lurid picture... it was the loss of strength to work for their betters or to fight for their country which struck the governing classes as important' (Alan D. Francis, The Wine Trade (London: Adam \& Charles Black, 1972), p. 157). The fear that over-consumption impedes production supersedes any moral concerns that might attend indulgence in alcohol. The mock georgics feature countless scenes of riotous debauchery as well and generally offer a more realistic representation of society than that found in their objects of parody.

18 Arthur Shadwell, Drink, Temperance and Legislation (New York: Longmans, Green, and Co., 1915), p. 48. 
ishes his countrymen to drink 'not too deep ... / The cup which luxury on careless wealth, / Pernicious gift, bestows' (4.670-72). Dyer's georgic draws an analogy between alcohol consumption and the allures of commerce, thereby departing from the tradition that seems to dictate the consumption of alcohol as a patriotic duty. Such georgics as $C y d e r$ and The Hop-Garden encourage the 'wholesome rules / Of temperance' (Cyd., 1.672-73), yet do not present alcohol, at least that which originates from 'British vats' (Cyd., 2.27), as the vice that it increasingly becomes in literary representation over the course of the century.

On the contrary, English georgics repeatedly endorse the consumption of 'native liquors' (Cyd., 1.26) over the 'vinous spirits' (Sugar., 4.602), which, in Grainger's text, potentially 'fire' the slaves 'to madness' (4.603) and prove the drink of choice for the debtor whose 'joys are short, and few' (p. 116) in Philips' poem. Ale and cider, by contrast, serve not only as 'symbols of good life, but also, albeit somewhat mystically, of natural virtues, as well' ${ }^{19}$ Accordingly, both Philips and Smart express a concern to downplay the harmful effects of alcohol and to emphasize instead its benign nature; this project proves of particular consequence to Philips who distinguishes the 'pulpous fruit' of his produce from that of the 'interdicted plant' (1.516) of Milton's Eden. Philips' 'hard cider' ideally serves to 'engender mirth' and to 'quell ... native phlegm' (2.328), while Smart's hops yield a 'generous beer' (1.133) and 'juice nutricious' (1.143). ${ }^{20}$ Grainger, meanwhile, describes the 'best produce' of the West Indies as 'heart-recruiting' (3.490) and productive of a 'blest ebriety' (4.506), with the adjective in this instance evoking the semi-religious quality surrounding the cult of Bacchus. All of these poets present their alcoholic beverages of choice as the nectar of paradise in the 'new Arcadia' of Merry England (or its colonial extension) in which the workers are but pastoral figures equipped with the instruments and trappings more familiar to the georgic. According to Crawford, 'Philips recasts England as an Eden whose fruit brings life rather than death' (p. 153), and his successors in turn render the associations between England and Arcadia intrinsic to the georgic mode, employing alcohol

19 William Gaunt, The World of William Hogarth (London: Jonathan Cape, 1978), p. 48.

20 Rudi Mattee notes that 'Beer and ale for centuries had provided nutrition for the labouring classes in northern countries' (p. 44). Furthermore, Hogarth offers as an alternative vision to 'Gin Lane' a depiction of 'Beer Street' that, according to Ronald Paulson, subscribes to the 'long tradition ... in which beer is opposed to gin as good to evil and, of course, industry to idleness' (Hogarth: His Life, Art, and Times, volume II (New Haven: Yale University Press, 1971), p. 102). 
as the primary means by which this identification is accomplished. Alcohol, accordingly, is necessarily productive rather than destructive, and altogether compatible with the pastoral vision of society elaborated within the georgics.

Thus, despite the georgics' unequivocal emphasis upon production, scenes of consumption nonetheless enter into the foreground of many of these poems. Philips recommends the labour-enhancing properties of drink in the form of a diluted cider, which 'the peasants blithe / Will quaff, and whistle as th[e] tinkling team / They drive, and sing of Fusca's radiant eyes, / Pleas'd with the medley draught' (2.105-10). Meanwhile, James Grainger, in much the same vein, exhorts that his reader 'Grudge not ... to let [his] slaves ... / Themselves regale with oft-repeated draughts of tepid Nectar ... / ... and make labour light' (Sugar., 3.40612). ${ }^{21}$ Alcohol becomes complicit in attempts to downplay the rigours of labour on the part of poets who subtly disguise the reality that 'consumption produces production by creating the necessity for new production' ${ }^{22}$ Both Grainger and Philips appear to subscribe to the notion that consumption of the product boosts production, a line of reasoning that ostensibly combines a sense of humanity with pragmatism, even while it places the labourer in an even more intimate relationship with his product, with the result that the labourer is not so much alienated from the product as absorbed into it. John Barrell observes this same fusion of labour and leisure in landscape painting that typically represents 'work, rest and play ... together, as all part of a harmonious image of the work of the farm' ${ }^{23}$ Yet, according to Barrell, the enterprise undertaken by both forms of art involves more than a mere union of play and work, but represents rather a 'peculiar alchemy' that converts 'labour into leisure,

21 Keith Sandiford explicates the role of otium in 'The Sugar-Cane,' in which 'georgic performs its definitive work of naturalizing slaves to the conditions of colonial acquisition, making them indispensable agents (though not beneficiaries) in the work of building civilization, while obfuscating the rigours of pain and loss that are inherent to their experience in these contexts' (The Cultural Politics of Sugar: Caribbean Slavery and the Narratives of Colonialism (Cambridge: Cambridge University Press, 2000), p. 80).

22 Karl Marx, Selected Writings, ed. David McEllan (Oxford: Oxford University Press, 1977), p. 24.

23 John Barrell, 'Sportive Labour: the farmworker in eighteenth-century poetry and painting' in The English Rural Community: Image and Analysis, ed. Brian Short (Cambridge: Cambridge University Press, 1992), p. 113. 
pain into pleasure'. ${ }^{24}$ English georgic elides the distinctions between production and consumption, creating thereby the illusion of oneness, as the pastoral and georgic appear to coexist in a simultaneous representation of play and work deriving less from Virgilian models than from eighteenth-century formal innovation. Whereas Virgilian georgic withholds the reward until the conclusion of labour, thus upholding more firmly the distinctions between labour and play, the English form pursues an agenda dictating that both the rigours and rewards of toil be represented, if not synchronously, as in Philip's and Grainger's works, then at least in closer proximity than is the case in Virgil.

It is important to note, however, that even while alcohol surfaces in the scenes of labour, it also asserts a presence at the end of exertion as well. The stock 'homecoming' scenes found in 'the poetry of labour' present drink as a compensation for productivity and a temporary escape from toil. In Stephen Duck's 'working-class' poem, 'The Thresher's Labour,' the speaker and his co-workers accept an invitation by their employer to 'feast with him at Night,' and find 'A Table plentifully spread ... / And jugs of humming beer to cheer the Mind, / Which he, too generous, pushes on so fast, / [They] think no toils to come, nor mind the past' (p. 11). Echoing the term employed by Duck in the narrative, John Goodridge characterizes this reward as a 'cheat,' which delusively 'reaffirms a pastoral vision at the end of a relentlessly georgic poem' (p. 79) ${ }^{25}$ Formal English georgics offer a variation on this topos, as they represent scenes of contented consumption at the conclusion of labor. In Philip's Cyder, ${ }^{26}$ the labourer, at close of day, entertains his 'honest friends' and 'with bounteous hand / Imparts his smoking vintage, sweet

24 Barrell, 'Sportive,' p. 113.

25 Pointing to the ominous use of intensifiers in this passage, Goodridge describes the harvest supper as a kind of 'crude anaesthetic, an ineffectual river of forgetfulness' (John Goodridge, Rural Life in Eighteenth-Century English Poetry (Cambridge: Cambridge University Press, 1988), p. 79). Yet, harvest supper scenes operate 'to confirm the essential solidarity of the English rural community... as landlord, tenant and labourer sit together in a spontaneous celebration' over the course of which 'the labourer is being bribed by beer... to accept the same obligations and the same discipline at the hands of his masters as he has accepted throughout the gruelling weeks of the harvest' (John Barrell, The Dark Side of the Landscape: The Rural Poor in English Landscape Painting, 1730-1840 (Cambridge: Cambridge University Press, 1980), p. 59). Alcohol functions as a hegemonic device wielded by the landowner to ensure the productivity of his tenants.

26 John Philips, 'Cyder,' Minor English Poets: 1660-1780. Vol. 2, ed. David R. French (London: Benjamin Blom, 1967), p. 106-18. 
reward / Of his own industry' (2.370-72). The libation in this context, rather than inducing the rustics to forget their labour, actually serves to remind them of it as Philips even goes so far as to declare that 'the thoughts of labour past / Increase their joy!' (2.375-76). But this drinking scene in turn prompts an extended simile that compares the refreshment of the rustics to the joy expressed by Philomel upon escaping her 'retentive cage' (2.377). With its violent undertow, the comparison actually highlights the harshness of the rustics' condition and elicits the reader's sympathy, considering that their alcoholic deliverance provides but a temporary escape in contrast to Philomel's permanent release. Still, the momentary rest afforded in these domestic scenes succeeds in softening as much as in recommending 'the moral lessons of Virgil's original Georgics to a polite English readership' according to John Barrell. ${ }^{27}$ While the analogous scene in Virgil's text represents the drinking of wine in the form of oblations to Bacchus, as '... the Herdsmen / Round the Chearful Fire, provoke his health in Goblets crown'd' (Dryden, 2.770-71), it is important to note that it does not present consumption for the sake of play as does the tradition of pastoral. Although English georgics draw upon the topos of alcoholic reward after the cease of toil, they do so with a view to conveying an ideological message directly related to maintaining a cheerfully industrious and wholly interpellated workforce. Philip's use of the term 'compotation' (italics mine) seems relevant to this discussion, since the prefix suggests the sort of collectivity and mutual effort that English georgic poets take such pains to underscore. In these works, the consumption of alcohol represents a social event and 'symbolizes the entire labour process, ${ }^{28}$ privileging the community to a degree that is utterly alien to the individualism espoused by the Virgilian georgic.

With the exception of this hearth scene crowning a day of toil, the Virgilian georgic focuses on a solitary labouring individual, while the English georgics repeatedly recreate the sense of communal sharing familiar to the pastoral that, at least temporarily, banishes the spectre of labour to the background. Virgil's celebration of rural secluded life, of

27 Barrell, Dark Side, p. 32.

28 Mikhael Bakhtin, Rabelais and his World, trans. Helene Iswolsky (Bloomington: Indiana University Press, 1984), p. 281. Although Bakhtin refers specifically to food, alcohol in the georgics performs an analogous function. 'In the oldest system of images food was related to work. It concluded work and struggle and was their crown of glory ... as the last victorious state of work, the image of food often symbolized the entire labour process ... the original system of images symbolized the working people, continuing to conquer life and food through struggle and labour...' (p. 281-82). 
the '... easie Quiet, a secure Retreat' (2.655), constitutes a topos of classical georgic that recurs in each of its English successors. James Sambrook interprets the English georgic's particular affinity for citing the 'happy husbandman' passage in the Virgilian original as a 'statement of the unalloyed aesthetic pleasure present in the rural landscape' (p. 195). In her work on English permutations of the beautus ille figure, Maren-Sofie Rostvig notes that 'certain late-seventeenth-century translators saw fit to invest the austere ideal ... with downright Hedonistic trappings ${ }^{29}$ preserved in some eighteenth-century treatments that employed the figure of the 'gentleman-gardener' as 'an impeccable front for ... Hedonistic indulgence in erotic pursuits' (p. 439). Hedonism, in the form of the 'tippling' farmer, enters the georgic landscape, as indulgence in alcohol becomes a means of temporarily dissolving the bonds of labour, and relaxing the didactic discipline considered central to the georgic. Representations of alcohol (and of figures consuming alcohol) continually erode the stoic temper of the form and introduce in its stead what may be loosely described as an ethos of Epicureanism.

It has been observed that the georgics' main concern 'is to present an image of English social life as in all important respects egalitarian and without conflict'. ${ }^{30}$ Alcohol, at least on the surface, becomes the leveler of distinctions between classes and the dissolver of hierarchy, as the georgics present landlords carousing freely with tenants and (more importantly) eulogize a type of alcohol accessible to the masses. Social historians of the eighteenth century note that whereas 'wine was the drink of the upper and upwardly mobile middle classes, ${ }^{, 31}$ cider and beer, the products of Philips' and Smarts' georgics, were 'drunk by many, especially in Herefordshire, Kent, and the western counties' (p. 241). In 'Cerealia,' we find that 'Tipple,' the yeoman's 'rude libation' proves itself superior to 'Frontiniac, or Bordeaux / Or old Falern ...' (p. 55-56) and all species of foreign vintage. ${ }^{32}$ Alcohol serves as 'a sign

29 The Happy Man: Studies in the Metamorphoses of a Classical Ideal 1600-1700 (Oxford: Basil Blackwell, 1954), p. 437.

30 Barrell, Dark Side, p. 38.

31 Kirsten Olsen, Daily Life in Eighteenth-Century England (Westport: Greenwood Press, 1999) p. 241.

32 As Kevin Cope notes, 'By casually admitting Bud Lite into the same cave with its more delicate colleagues, Philips' easygoing readers are implicated in a strangely incorporative rout of outlandish libations' (Kevin L. Cope, 'When the Past Presses the Present: Shillings, Cyder, Malts, and Wine,' in Reader Entrapment in Eighteenth-Century Literature, ed. Carl R. Kropf (New York: AMS Press, 1993), p. 23). 
of social ideology and an index of cultural meaning, ${ }^{, 33}$ and georgics wield it consistently as a tool of hegemony. It cannot be accidental that Gay writes in his 'A Ballad. On Ale,' sing, / Or talk of freedom, church, and king ... / While his rich landlord lays out schemes / Of wealth, in golden South Sea dreams' (p. 49-53). Ostensibly, the egalitarian ethos embodied in specific types of alcohol enables the georgic writers to dissolve the conventional oppositions between the poor and the aristocracy, which cast the former segment of society in the role of producers and the latter in the role of consumers. But it is arguable that the georgics, with 'their unequivocally reactionary biases, ${ }^{35}$ concern themselves with tempering this image of the rural worker as purely productive by presenting him in moments of consumption. At the same time, the productivity of the upper-classes is represented in the art and poetry of the period through images of 'gentry and labourers working together on the land for the common good. ${ }^{36}$ The georgics cast the workers as productive consumers through the use of alcohol, and enable them to enjoy an element of the leisure typically associated with the pastoral, even while they offset the landowner's reputation for idleness.

The georgics under scrutiny consistently equate the rural worker with the product of his or her labour, in a manner consistent with the tendency of labour 'not only [to] produce commodities' but 'to produce itself and the labourer as a commodity' (p. 78). Smart's The Hop-Garden ${ }^{37}$ offers an illustration of this transformation in its rather charming vignette of 'sportive labour' near the conclusion of the hop-curing process. As the day's labour draws to a close, the now 'exulting band / Of pickers male and female' (2.181-82) bury themselves in the 'bellying bin' (2.177), and thereby become integrated into the product of their labour. By incorporating themselves into the crop and the receptacles that contain it, the workers arguably assert a bodily identification with the commodity to

33 Robert James Merrett, 'Bacchus in Restoration and Eighteenth-Century Comedy: Wine as an Index of Generic Decline,' ed. Marie-Laure Girou-Swiderski (Edmonton: Academic Printing \& Publishing, 1988), p. 180.

34 John Gay, 'A Ballad. On Ale,' John Gay: Poetry and Prose, Vol. 2, ed. Vinton A. Dearing (Oxford: Clarendon Press, 1975).

35 O'Brien, p. 166.

36 O'Brien, p. 166.

37 Christopher Smart, 'The Hop-Garden. A Georgic,' The Poetical Works of Christopher Smart, ed. Karina Williams (Oxford: Clarendon Press, 1987), p. 41-65. 
which they have been subordinated throughout the georgic. ${ }^{38}$ While this comic detail could undoubtedly suggest Smart's attempt at parody of the Virgilian original, we might also interpret it as part of this author's general tendency to deride the hop-garden labourers themselves, whom he describes at one point as a 'mob / Irrational' (2.157-58) and elsewhere as a 'rebel rout' (2.154). Moreover, in his simile likening the 'industrious vulgar' to 'prudent bees' that 'In Kent's wide garden roam, expert to crop / The flow'ry hop, and provident to work' (2.58-60), Smart strikingly reverses the Virgilian trope of the fourth georgic in which the activity of the 'lab'ring bees' is ennobled through extended analogy with that of human workers. Smart's manœavre actually succeeds in depreciating his labourers as it measures them merely in terms of the value of their labour, just as his depiction of their play attempts to pastoralize the georgic situation, but falls short of mitigating the rigours of the toil earlier described.

Furthermore, just as the identities of the georgic labourers prove contingent upon the commodities they produce, so too does the soil which cultivates the products. The georgics translate the landscape into an object of consumption, a 'fetishized commodity ${ }^{\prime 39}$ that derives its primary value from the crop cultivated within its physical compass. Hence, when the speaker of Cyder exhorts his addressee to survey the 'meadows here,' he directs the readers' attention primarily to how the field 'with barley-grain / Stands thick, o'ershadow'd to the thirsty hind...' (p. 555-56). Philips constructs the view from the perspective of the labourer, the 'thirsty hind' for whom the landscape signifies nothing more than the product 'composed' from it: the 'auburn drink ... / Wholesome of deathless fame' (1.557-58). Whereas Philips initiates his poem with a description of 'Cyder-Land,' Smart notably resists describing the landscape of 'hop-land' until he has guided his agricultural acolyte through the full process of cultivation and has produced the desired effects at the end of the first book. Only then are the 'florid hops' seen to bloom '... and in the stream / Shine in their floating silver, while

38 Ann Bermingham observes that 'most of the rustic landscape' found in eighteenth-century paintings 'skirt the question of ownership, and the figures look as though they belong to the land and not vice versa' (Landscape and Ideology: The English Rustic Tradition, 1740-1860 [Berkeley: University of California Press, 1986], p. 41), and this subordination of the individual to the land surfaces repeatedly in English georgic as well.

39 William John T. Mitchell, 'Imperial Landscape,' in Landscape and Power, ed. William John T. Mitchell (Chicago: University of Chicago Press, 1994), p. 15. 
above / Th'embow'ring branches culminate, and form / A walk impervious to the sun' (1.345-50). The landscape, in Smart's georgic, assumes meaning only when it is physically transformed by the worker and displays the product of labour, functioning essentially as a showcase or shop-front for the produce, in much the same manner as does the poem itself. Britain, moreover, becomes assimilated into the product of rural labour and derives its identity from this commodity, assuming the name of 'Cyder-land' initially, then 'Hop-Land' in Smart's poem, and still later, becoming associated in a colonial context with the 'Cane-Isles' of Grainger's Caribbean. As the descriptive impulse overrides the instructive inclination so marked in the Virgilian original, the English soil achieves increasing prominence. ${ }^{40}$ The 'georgics of drink' in the English tradition concentrate upon a single product which eclipses the figure of the rustic, thus imparting a static quality to the landscape more reminiscent of the 'golden stasis' characteristic of pastoral ${ }^{41}$ than of the hectic activity typical of georgic. The landscapes of the English georgics thus differ considerably from those of the classical form in which the labour of the rustic assumes priority over nature itself. ${ }^{42}$

The product, moreover, serves to promote the cause of British nation-building, as English georgic repeatedly contrasts the plenitude of British landscape with that of foreign vistas. Philips, in setting the scene for his Herefordshire georgic, describes how '... Autumn paints / Ausonian hills with Grapes; whilst English plains / Blush with

40 Virgil's assurance to his georgic reader that he will not stray from the realm of didactic verse is conveyed in the following lines: '...non hic te carmine ficto /Atque per ambages et longa excorsa tenebo' (2.45-46).

41 Alistair Fowler, Kinds of Literature: An Introduction to the Theory of Genres and Modes (Cambridge: Harvard University Press, 1982), p. 254.

42 Addison extends his somewhat elitist treatment of the Georgics by describing the subject that the Georgics 'goes upon, as the meanest and least improving' although he does allow that it is also 'the most pleasing and delightful in that it addresses itself wholly to the imagination. It is altogether conversant among the fields and woods, and has the most delightful part of nature of its province. It raises in our minds a pleasing variety of scenes and landskips' (Joseph Addison, 'Preface to Dryden's Translation of the Georgics,' in Works of John Dryden [London: Ballantyne Press, 1808], p. 211). Addison emphasizes the visual evocativeness of the georgic, its ability to conjure up in the mind images of the landscape, which accordingly comes to be viewed as the invention of humanity rather than the pure work of nature. The ability to produce landscape through a verbal mapping out of space suggests Simon Schama's thesis in Landscape and Memory (New York: Random House, 1996) that landscape itself is a work of the mind. 
pomacious harvests, breathing sweets' (2.24-27). The choice of verbs to denote the respective landscapes proves illuminating; the foreign scenes are 'painted,' evoking associations with artifice and masquerade, whereas the English countryside 'blushes' with an innocence reminiscent of its Edenic analogue. John Gay's mock georgic ${ }^{43}$ 'Wine, ${ }^{44}$ offers an indictment of this imported 'vice' that entices the 'British Marriner' [sic] from his 'native shore' and familial concerns. Gay evokes a Mediterranean landscape of lurid sensuality, wherein '... the Purple Grape / In largest Clusters Pendant, Grace the Vines / Innumerous, in Fields Grottesque [sic] and Wild / They with Implicit Curles the Oak entwine, / And load with Fruite Divine her spreading Boughs' (p. 81-85). In contrast to the Arcadian simplicity of the English countryside, its continental counterpart embodies a ripe post-lapsarian quality at once seductive and sinister with its imagery of serpentine embrace. In deviating so markedly from its Virgilian-Roman equivalent, the British georgic landscape asserts a national distinctiveness that does not so much transplant the Roman author into an English context, but rather supplants him altogether.

The English georgics typically end on a rousingly patriotic note, in keeping with the 'connection between nation-building and poetic modes celebrating labour' that Rachel Crawford sees as 'central in the tradition established by Virgil's Georgics' (p. 125). Philips initiates this trend for the English georgics in his proclamation that '... where'er the British spread / Triumphant banners, or their fame has reach'd / Diffusive, to the utmost bounds of this / Wide universe, Silurian cider ... / Shall please all tastes, and triumph o'er the vine' (2.667-71). Philips' vaunting boast finds an echo in the prediction at the end of The Hop-Garden that '... France / Shall bow the neck to Cantium's peerless offspring, / And

43 Gay's poem, published in 1708, a year after 'Cyder,' is described by Margaret Anne Doody as 'a comic answer to John Philips' "Cyder"' (The Daring Muse: Augustan Poetry Reconsidered (Cambridge: Cambridge University Press, 1985), p. 114). As Doody writes, it is Gay's contention that 'Had Philips been inspired by wine ... he would have equalled his own previous work, but his Muse has suffered from too much cider' (p. 114). Gay's avowed intention to sing 'Of Happiness Terrestrial, and the Source ... Of Sparkling Juices, of th'enlivening Grape' (p. 1-3) expressly suggests georgic convention, as does the invocation to the muse in the poem's second paragraph: 'Bacchus Divine, aid my adventurous Song, / That with no middle flight intends to soar. / Inspir'd, Sublime on Pegasean Wing / By thee upborn, I draw Miltonic Air' (p. 12-15).

44 John Gay, 'Wine,' John Gay: Poetry and Prose, Vo. 1, ed. Vinton A. Dearing (Oxford: Clarendon Press, 1974). 
as the oak reigns lordly o'er the shrub / So shall the hop have homage from the vine' (2.301-304). But, whereas Philips' conclusion underscores Britain's image as a conquering nation, Smart's treatment favours the portrayal of its governing role. John Dyer reiterates this same message in The Fleece as he demands in reference to Britain, 'What can avail to her ... / The arm'd host, and murdering sword of war, / And conquest o'er her neighbours?' (4.658-59), and insists instead that 'Tis her delight / To fold the world with harmony, and spread ... / The various wealths of toil' (4.660-67). As the English georgics mature, the vision of imperial acquisition transmutes into a more subdued ideal of imperial preservation in Smart's and Dyer's works. ${ }^{45}$ Yet, despite this paradigm shift in ideology the central metonyms are preserved, as England's relations with France continue to be represented through the primary alcoholic commodity peculiar to each nation.

Even despite extending the invitation to Bacchus 'to strip off [his] buskins and with [him] plunge [his] naked legs in the new must, ${ }^{\prime 46}$ Virgil's speaker in the Georgics remains virtuously sober and reliant upon the muses to 'direct his song.' Thus, although 'drink' does unquestionably assert a presence in Virgil's landscapes of labour, it figures much more prominently in the bucolic scenes of the Eclogues, which feature speakers such as Silenus, Bacchus' mentor and companion, who regales his shepherd audience with tales inspired by 'yesterday's wine' (Ec., 6.13). The leisurely world of the pastoral accommodates Dionysian myth and its aesthetic view that 'poetry and Bacchus, wine and inspiration... are clearly connected ideas. ${ }^{47}$ Philips demonstrates an appreciation of this notion in Cyder, in which his inspiration, as noted by Dustin Griffin, 'is caused not by the nightly visits of the muse, but by timely draughts of cider' ${ }^{48}$ At one juncture, Philips bids his reader 'See! the

45 Linda Colley points out that the Seven Years War confronted Britons with the problem of having acquired too much power too quickly over too many people' (Britons: Forging the Nation, 1707-1837 [New Haven: Yale University Press, 1992], p. 102); she argues that 'the success had been too great, the territory won was at once too vast and too alien' (p. 101). The concern expressed by the later georgics with preserving rather than acquiring territory may be directly attributable to this particular dilemma.

46 Virgil: with an English translation, trans. Henry Rushton Fairclough (Cambridge: Harvard University Press, 1935) p. 137.

47 Williams, p. 111.

48 Dustin Griffin, 'The Bard of Cyder-Land: John Philips and Miltonic Imitation,' Studies in English Literature 24 (1984): p. 452. 
Numbers flow / Easie, whilt, chear'd with her nectareous Juice, / Hers, and my country's Praises I exalt' (1.521-23), and he later declares his absolute dependence upon 'humid regalement,' insisting that 'Nor can the poet Bacchus' praise indite, / Debarr'd his grape' (2.389-99). In Philips' 'The Splendid Shilling,' the poet, 'Thoughtful of Drink, and eager in a Dream, / Tipples Imaginary Pots of Ale; / In vain ...' (p. 109-111). Smart similarly extols alcohol's power 'to enlarge, / To glad the heart, to sublimate the mind, / And wing the flagging spirits to the sky' (1.57-59). But, whereas 'buxom beer' (1.63) buoys up Smart's muse, in The Sugar-Cane, Grainger derives his inspiration from 'heart-recruiting rum' (3.489), confiding how his soul 'dilates ... with genuine joy' and 'toil a pleasure seems' when he quaffs a bowl of the beverage (3.494-500). All three poets, through personal consumption of the products they praise, both advertise the merits of alcohol and assert their kinship with the labourer, thus adhering to the tradition established by the Virgilian Georgics, which draws incessant analogies 'between the act of ploughing the field and writing on the page. ${ }^{\prime 49}$ The centrality of alcohol to the process of composition attracts parody in the 'Saturday' installment of Gay's 'Shepherd's Week' which finds the rustic Bowzybeus transformed into a Georgic poet, who, inspired to 'Sublimer Strains' (p. 1) by a drink 'wondrous strong!' (p. 32), sings of 'How Turnips hide their swelling Heads below, / And how the closing Colworts upwards grow' (p. 55-56). Mock-georgic thrusts into the foreground the inconsistencies of the form itself and amplifies the sympotic spirit intrinsic to the English reworking of the classical model. In turning to the fruits of Bacchus and the symposium for their inspiration, the English georgic poets embrace their accompanying 'collective, free, enthusiastic acceptance of life ${ }^{\prime 50}$ and thereby exchange georgic for pastoral convention.

Finally, it is noteworthy that quite often in English georgics we find the figure of Bacchus, toiling alongside the rustic labourer. Bacchus asserts a physical presence and even presides in The Hop-Garden as a 'Hop-Master,' where 'straddling cross the bin / He with pride of heart surveys / Obedient mortals...' (2.52-56). In Philips' 'Cerealia, ${ }^{, 51}$ he is '...

49 Heinzelman, p. 191.

50 Andre Winandy, 'Rabelais' Barrel,' in Intoxication and Literature, Yale French Studies 50 (1974): p. 8.

51 'Cerealia,' a poem typically ascribed to Philips, features a debate between Bacchus and Ceres concerning which of their products proves the most beneficial to England, in which Ceres emerges the victor as 'With Ale ... Heaven's capacious goblet [is] crown'd' (John Philips, 'Cerealia,' in Minor English Poets: 1660-1780. Vol. 2, ed. David 
by his plump cheeck and barrel belly known' (p. 118), while Thomas Parnell's poem presents the god as '... ranging at his leisure' (p. 1) and overseeing the 'labour hard' (p. 21) of his worker fauns. ${ }^{52}$ While each of these poems present a distinct version of Bacchus, they all agree in assigning him an integral role in casting him physically as a character. Although Virgil invokes Bacchus' aid in the Georgics, calling upon Liber, his ancient Italian incarnation, at the outset of the first book, and then, in Dryden's translation of the second book, inviting him 'Come strip with me ... come drench all o'er / Thy Limbs in Must of Wine, and drink at ev'ry Pore' (2.11-12), the god does not actually appear within the text itself. Pastoral tradition, however, accommodates Bacchus and his spirit of revelry much more readily and, as Anya Taylor notes, peoples the landscape with recognizably 'Dionysian figures'.$^{53}$ Indeed, the fifth eclogue indulges in a Bacchanalian spirit, in its allusions to 'merry meetings where the wine will flow' and to 'tankards filled with the fresh nectar of the China grape' (p. 73). Bacchus becomes a hedonistic figure in the anglicized Arcadian landscape and acts as a relic or remnant of the pastoral in its most primitive form. It might be argued, moreover, that Bacchus' presence in the English georgic repastoralizes the form and emphasizes the state of play with which the god is associated.

Although my reading of eighteenth-century English georgics indisputably subscribes to a 'hermeneutics of suspicion,' it does so with a view to exposing to just what extent the question of consumption, or more specifically, 'compotation,' really was a matter of dire import for its authors. Both in its 'serious' and parodic forms, English georgic employs alcohol consistently as a means of rendering generic distinctions more fluid and of vexing typical constructions of labour and leisure as they pertain to the organization of class in society. Intended for the consumption of a readership assuredly divorced from the conditions of

R. French (London: Benjamin Blom, 1967), p. 119). A 'pendant-piece' to 'Cyder,' this poem is usually thought to have inspired the georgic.

52 Although Thomas Parnell's poem "'Bacchus"; or, a Drunken Metamorphosis' is not described formally as a georgic, the Bacchus figure enjoins his 'jolly Fauns' to work the land, and the third stanza features a georgic scene wherein, under the god's personal supervision, 'While oft he calls to labour hard, / And names as oft the sure reward.' Thomas Parnell, 'Bacchus; or, the Drunken Metamorphosis,' in Minor Poets of the Eighteenth Century: Parnell, Green, Dyer \& Anne, Countess of Winchilsea, ed. Hugh I'Anson Fausset (London: J.M. Dent, 1930).

53 Bacchus in Romantic England: Writers and Drink, 1780-1830 (London: Macmillan Press, 1999), p. 8. 
labour, the georgic presents a labouring figure caught up in an inexorable cycle of production and consumption and wholly eclipsed by the operations at both ends of the labour continuum.

KELLY ANN MCGUIRE

University of Western Ontario 